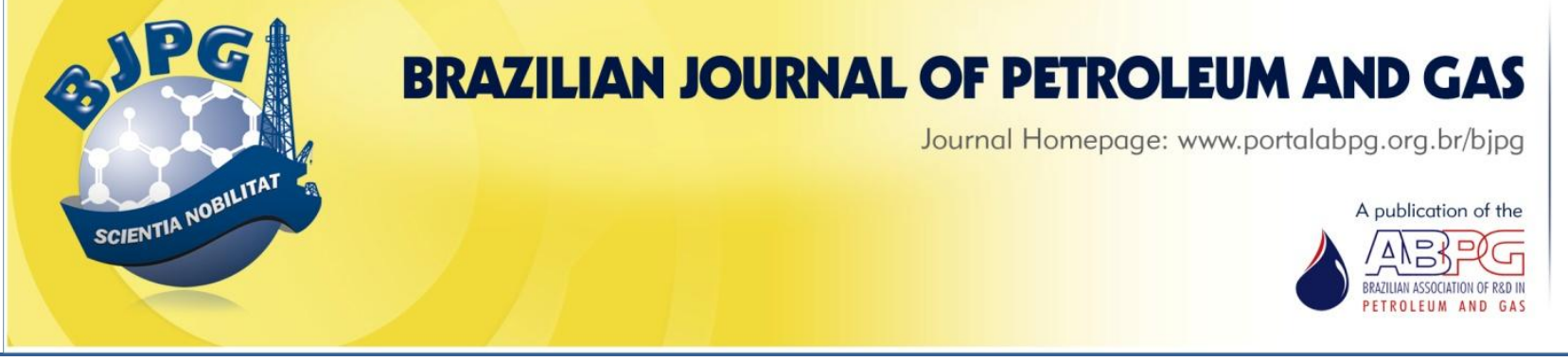

\title{
SELECTION, ISOLATION AND GROWTH KINETIC STUDY OF A BACTERIAL CONSORTIUM OBTAINED FROM THE POTENGI MANGROVE IN THE PRESENCE OF CRUDE OIL
}

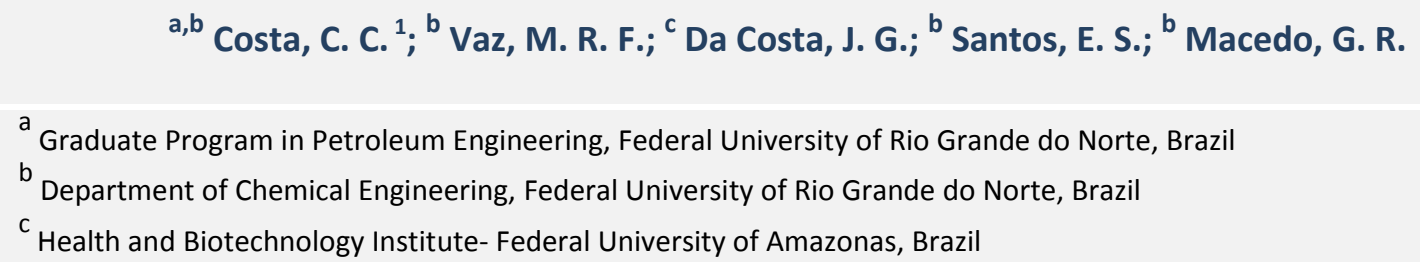

\section{ABSTRACT}

The selection, isolation and kinetic study of a bacterial consortium obtained from a sample of soil from the Potengi mangrove, located in the city of Natal, Rio Grande do Norte, Brazil, has been carried out using the enrichment culture technique to observe aspects such as the evaluation of main growth parameters. The kinetic study used a rotary incubator shaker at $150 \mathrm{rpm}$, under $30^{\circ} \mathrm{C}$. The bacterial consortium isolated from the estuary of the Potengi River showed a good acclimation in minimum mineral medium with $1 \%$ $(\mathrm{v} / \mathrm{v})$ of oil. The cell concentration reached $2.55 \mathrm{~g} / \mathrm{L}$ at $16 \mathrm{~h}$ of cultivation and surface tension dropped. The maximum productivity in cells obtained was of $0.3 \mathrm{~g} / \mathrm{L} . \mathrm{h}$, the specific velocity of growth was of $0.075 \mathrm{~h}^{-1}$, with a generation time $(\mathrm{tg})$ of $9.24 \mathrm{~h}$. This study seeks to demonstrate that the consortium can be used as inoculants in biological treatments, capable of reducing the waste's degradation time.

\section{KEYWORDS}

mangrove; enrichment cultures; kinetic; oil; bacterial consortium

\footnotetext{
${ }^{1}$ To whom all correspondence should be addressed.

Address: Department of Chemical Engineering, Federal University of Rio Grande do Norte, Av. Senador Salgado Filho 3000, Natal (RN), Brazil | CEP: 59072-970

Telephone: +55 8432153769 r. 214 | E-mail: natcintia@gmail.com doi:10.5419/bjpg2011-0021
} 


\section{INTRODUCTION}

For decades, the incidence of oil pollution and its threats have led to the development of extensive research efforts seeking to minimize environmental damage. The anthropogenic impact on the environment through the extraction of petroleum represented a fate for the environment. Tanker accidents are considered the major causes of oil pollution in marine environments (Chaerun et al., 2004). Large spills of oil and related petroleum products in the marine environment can have serious biological and economic impacts (Fingas and Brown, 1997). Oil spills are known to cause severe and long-term damage to mangrove ecosystems (Wardrop, 1987; Burns et al., 1993; Duke et al., 1997; Duke et al., 2000; Antonio et al., 2011).

Since the pioneering work on marine bacteria by ZoBell (ZoBell, 1946), many bacterial strains capable of degrading petroleum hydrocarbons have been isolated from coastal and oceanic environments. Many of these bacteria are isolated through the use of conventional enrichment techniques, having the petroleum hydrocarbons as the source of both carbon and energy (Bouchez et al., 1995; Liu et al., 2010). The search for novel ways to isolate, select and cultivate diverse petroleum-degrading bacteria inhabiting marine environments has interested numerous researchers throughout the world (Harayama et al., 2004; Vasconcellos et al., 2009; Zhang et al. 2010).

The enrichment-culture technique allows the isolation of pure cultures of bacteria and fungi, which are able to use a large number of organic molecules to obtain carbon and energy. The method is based on the selective advantage gained by an organism that has the ability to use a particular test compound to get carbons and energy in a medium containing inorganic nutrients but no other sources of carbons and energy (Alexander, 1999). Under these conditions, solely the species that are able to grow by utilizing carbons will multiply. A limited number of bacteria and fungi will proliferate in this medium. Vast literature address studies in the area of microbial consortia and enrichment (Atlas, 1981; Leahy and Colwell, 1990; Liu et al., 2010; Guo et al., 2010).

Actually there is a great effort in the development of techniques that can be used in order to reduce oil spill. The primary objective of this study is to isolate bacterial strains capable of utilizing crude oil in order to obtain a consortium of hydrocarbon-degrading bacteria. This study describes the results of an effort to isolate and assay a kinetic growth of a bacterial consortium isolated from a mangrove estuary river for possible use in recovery proceedings of polluted areas nearby.

\section{MATERIALS AND METHODS}

\subsection{Study area and sampling}

The sediment samples were collected from the mangrove area of the Potengi estuary, see Figure1. The Potengi estuary is located in the state of Rio Grande do Norte, in the northeastern geographical area of Brazil (05844VS and 35811VW, 05851VS and $35821 \mathrm{VW}$ ). It is formed by the waters of the Potengi, Jundiaí and Doce rivers (Ramos e Silva et al., 2006). The selected site is under intense anthropic actions, which are responsible for the severe environmental damage caused to the river. Human action is threatening the sustainability of the river's ecological and social potential (Sindern et al, 2007). The local marine ecosystems are susceptible to oil contamination caused by a possible accidental spill (Frazão, 2003).

Surface sediment samples with sizes of up to $5 \mathrm{~cm}$ were collected randomly in triplicate from an area of around $1 \mathrm{~m}^{2}$ at the center of each mangrove transect area during low tide. Sediments samples were transferred to $100 \mathrm{~mL}$ sterilized plastic bottles for microbiological analysis within $24 \mathrm{~h}$ of collection and transported to the Biochemical Engineering Laboratory of the Federal University of Rio Grande do Norte, UFRN, in an icebox and stored in a dark room. A global positioning system was used to determine the sampling positions.

\subsection{Enrichment cultures}

The selection of hydrocarbon-degrading microorganisms was made using the technique of enrichment cultures (Koizumi et al., 2002; Nakagawa et al. 2002, 2008). Enrichment cultures were prepared by adding $10 \mathrm{~g}$ of sample soil in mineral salt medium (Furukawa et al., 1978) with $1 \%$ of crude oil as the carbon source. The mineral 


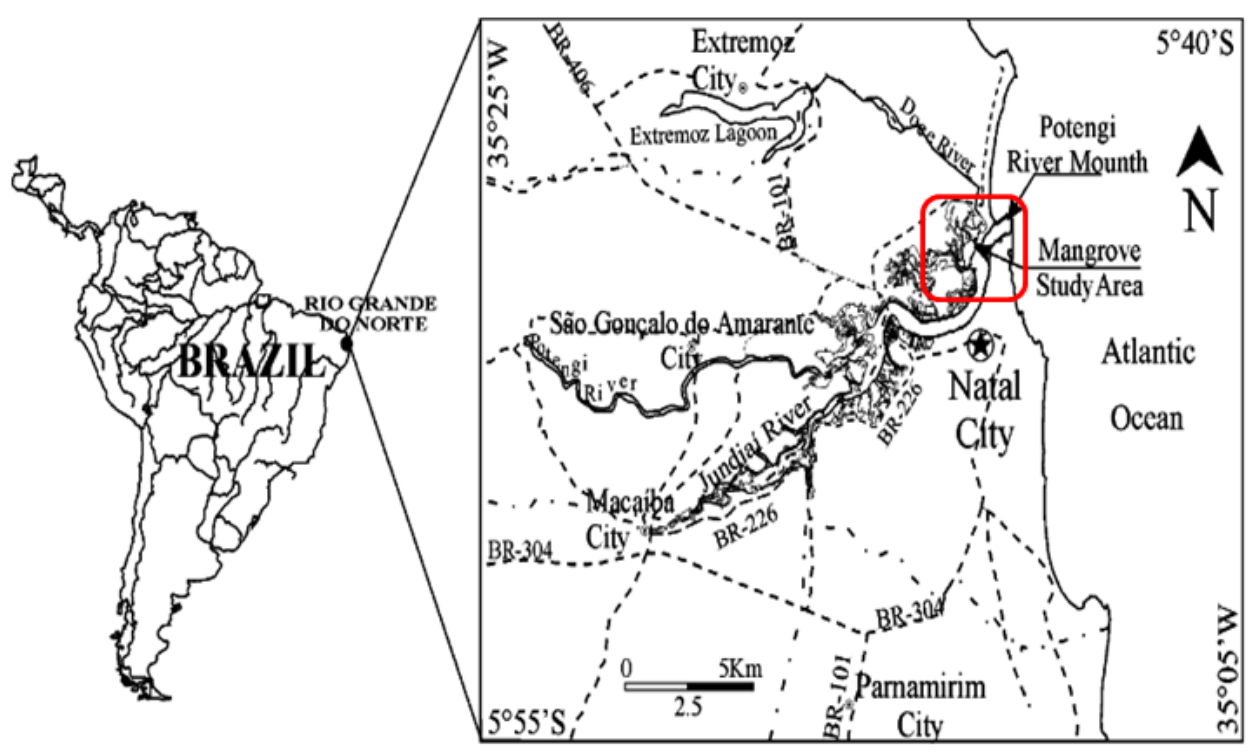

Figure 1. The map of the site under study (Ramos e Silva et al., 2006).

medium contained (per Liter of deionized water) $1.0 \mathrm{~g}\left(\mathrm{NH}_{4}\right)_{2} \mathrm{SO}_{4}, 0.2 \mathrm{~g} \mathrm{KH}_{2} \mathrm{PO}_{4}, 1.6 \mathrm{~g} \mathrm{~K}_{2} \mathrm{HPO}_{4}, 0.2 \mathrm{~g}$ $\mathrm{MgSO}_{4} \cdot 7 \mathrm{H}_{2} \mathrm{O}, 0.1 \mathrm{~g} \mathrm{NaCl}, 0.01 \mathrm{~g} \mathrm{FeSO}_{4} \cdot 7 \mathrm{H}_{2} \mathrm{O}$, and $0.02 \mathrm{~g} \mathrm{CaCl}_{2} \cdot 2 \mathrm{H}_{2} \mathrm{O}$ (Furukawa et al., 1978; Sakata et al., 2004). The cultures were incubated on a rotary shaker (430 Benchtop Incubator Shaker, Nova Ética) at $150 \mathrm{rpm}$ and $30^{\circ} \mathrm{C}$ until growth could be observed, which occurred approximately after 7 days. Following three serial transfers in the enrichment medium utilizing the spread plate technique (APHA, 1999), the cultures were poured onto a marine agar (B D Difco ${ }^{\mathrm{TM}}$ ) medium with $1 \%$ crude oil in a Petri dish. The plates were incubated at $30^{\circ} \mathrm{C}$ for 5 days. Then, all colonies that differed in appearance were picked and streaked two more times in order to isolate the colonies. As control, flasks containing mineral medium and crude oil without sediments were incubated at the same temperature as the actual samples ones.

\subsection{Preliminary identification}

The preliminary identification step was performed by Gram stain. All gram-positive and gram-negative results obtained by Gram staining were confirmed by $\mathrm{KOH}$ method. To perform the test, place a drop of $3 \%$ aqueous $\mathrm{KOH}$ on a slide. Using a sterile loop, transfer a visible amount of bacterial growth from on agar culture to the drop of $\mathrm{KOH}$. Mix the cells and $\mathrm{KOH}$ thoroughly on the slide, constantly stirring over an area about $1.5 \mathrm{~cm}$ in diameter. If the bacterium- $\mathrm{KOH}$ suspension becomes markedly viscid or gels within 5 to $60 \mathrm{~s}$, the isolate is gram negative. If no gelling is observed, is gram positive (Buck, 1982). All cultures were checked for the purity using an optical microscope.

\subsection{Bacterial consortium}

An oil degrading microbial consortium was obtained with the use of the enrichment culture technique (Jacques et al., 2008). This consortium was composed of ten bacteria, being five grampositive and five gram-negative. The bacterial isolates were stored separately in a marine agar medium with $1 \%$ of crude oil at $4^{\circ} \mathrm{C}$ (Costa, 2005, 2010). Cells of each isolate were transferred to Erlenmeyer flasks, with $250 \mathrm{~mL}$ capacity, containing $90 \mathrm{~mL}$ of the mineral medium plus $1 \%$ of crude oil as sole carbon source. The flasks were sterilized by autoclaving at $121^{\circ} \mathrm{C}$ for $20 \mathrm{~min}$ and incubated in orbital shaker $(150 \mathrm{rpm})$ at $30^{\circ} \mathrm{C}$. The mineral medium used was the same as the one used in item 2.2. The pH was adjusted to 7 (Sakata et al., 2004). After $96 \mathrm{~h}, 100 \mu \mathrm{L}$ of this culture of the microbial consortium was transferred to a marine agar medium which had $1 \%$ of oil. The culture was spread on the plate surface and incubated at $30^{\circ} \mathrm{C}$ for $72 \mathrm{~h}$. Thereafter, $5 \mathrm{~mL}$ of sterile water was added to the plates and the consortium colonies were collected in the tube. The cell suspension was 
centrifuged by a Eppendorf model 5415D centrifuge under $13,000 \mathrm{rpm}$, for 15 minutes at $25^{\circ} \mathrm{C}$. The pellet was suspended in a given volume of sterile water. Erlenmeyer flasks of $250 \mathrm{~mL}$, containing $89 \mathrm{~mL}$ of mineral medium and $1 \mathrm{~mL}$ of crude oil were inoculated with $10 \mathrm{ml}$ of the cell suspension of the microbial consortium, introducing a population of $2.0 \times 10^{8} \mathrm{CFUg}^{-1}$ (Kästner et al., 1998; Sakata et al., 2004).

After the inoculation, the Erlenmeyer flasks were incubated in an orbital shaker under $150 \mathrm{rpm}$ at $30^{\circ} \mathrm{C}$ and the microbial consortium was assayed for kinetic growth. In order to obtain the samples' kinetic growth, the study samples were kept under agitation of $150 \mathrm{rpm}$ at $30^{\circ} \mathrm{C}$. During a period of 32 hours, divided in four hour increments, the consortium's biomass, surface tension, specific growth rate, generation time, and productivity were checked.

\subsection{Biomass content (X)}

The cell density was determined by measuring the culture's optical density, $O \mathrm{D}$, at $615 \mathrm{~nm}$ with a Genesys 10 UV Thermo Spectronic spectrophotometer. The cell concentration was obtained by calculating the dry cell weight. The determination of the weight of the dried out cells' was achieved by centrifuging the sample broth at $13,000 \times$ for 15 min and, then, drying the cell to a constant weight at $80^{\circ} \mathrm{C}$ (Shim et al., 2005).

\subsection{Productivity in cells $\left(P_{x}\right)$}

The productivity of biomass $\left(P_{x}\right)$ is an important parameter for evaluating the performance of a fermentation process (Liria, 1995). It represents the increase of cell concentration $(\mathrm{g} / \mathrm{L})$ during a given time interval (t-to) ( $h$ ), as seen in Equation 1.

$\mathrm{P}_{\mathrm{X}}=\frac{\mathrm{X}_{\mathrm{F}-} \mathrm{X}_{0}}{\mathrm{~T}_{\mathrm{F}}}$

where, $P_{x}$ is the productivity in cells $(g / L h), X_{F}$ is the final cell concentration $\left(\mathrm{g} \cdot \mathrm{L}^{-1}\right), \mathrm{X}_{0}$ is the initial cell concentration $\left(\mathrm{gL}^{-1}\right)$, and $T_{F}$ is the final time (h).

\subsection{Determination of the surface tension $(\mathrm{mN} / \mathrm{m})$}

Surface tension measurements were performed by the Wilhelmy plate method using the Krüss K100MK2 tensiometer (Klomfar et al., 2010). In the plate method the liquid is raised until the contact between the surface or interface and the plate is registered.

The tension is calculated using the following Equation 2:

$\sigma=\frac{F}{L \times \cos \theta}$

where, $\sigma$ is surface or interfacial tension, $F$ is auf force acting on the balance, $L$ is wetted length and $\theta$ is contact angle

\subsection{Specific growth rate}

The kinetic parameters were obtained according to Baily and Ollis (1986) and Ahmad and Holland (1995). The specific growth rate, $\mu$, is a measure of how quickly the cell population is growing. The higher the value of $\mu$, the greater the consortium growth is. Specific growth rates, at different times, were determined numerically after fitting the cell mass concentration to a polynomial function and performing further calculations. Equations (3) and (4) show the formulas used to determine the consortium's growth rate. In the following equations, $\mu$ is the specific growth rate $\left(h^{-1}\right), X$ is the cell concentration $\left(\mathrm{g} \cdot \mathrm{L}^{-1}\right)$, and $\mathrm{t}$ is the time $(\mathrm{h})$.

$\frac{\mathrm{dX}}{\mathrm{dt}}=\mu_{\max } \cdot \mathrm{X}$

where, $\mu_{\max }$ is the maximum specific growth rate of the microorganism $\left(\mathrm{h}^{-1}\right), \mathrm{dX}$ is the variation in cell concentration $\left(\mathrm{g} \cdot \mathrm{L}^{-1}\right), \mathrm{dt}$ is the change in time $(\mathrm{h})$, and $X$ is the cell concentration (g. $\mathrm{L}^{-1}$ ). 


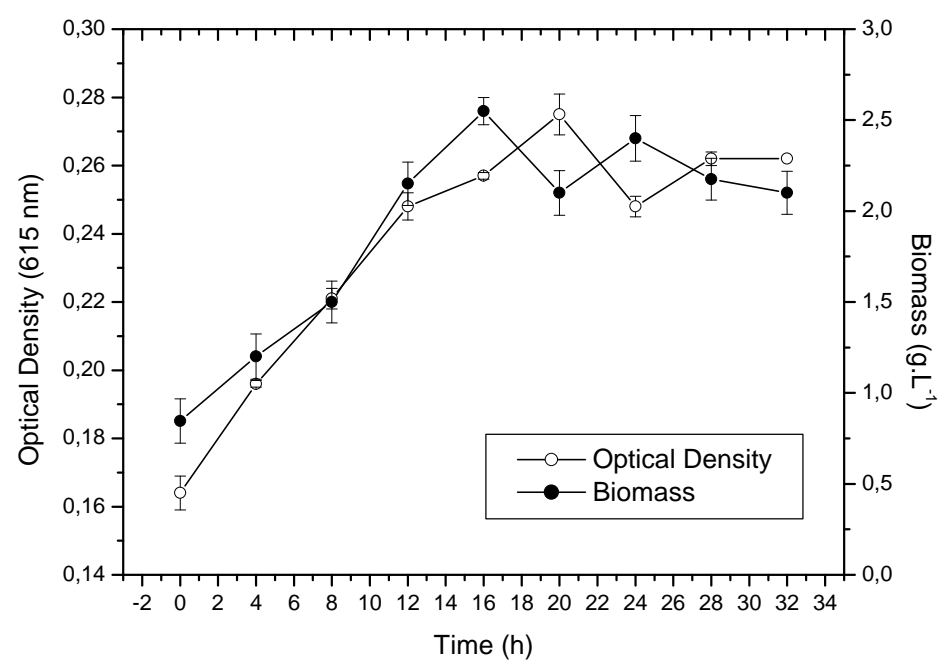

Figure 2. The growth curve of the bacterial consortium in mineral medium. The graph shows the behavior of the optical density (०) and the biomass $(\bullet)$ in a given time.

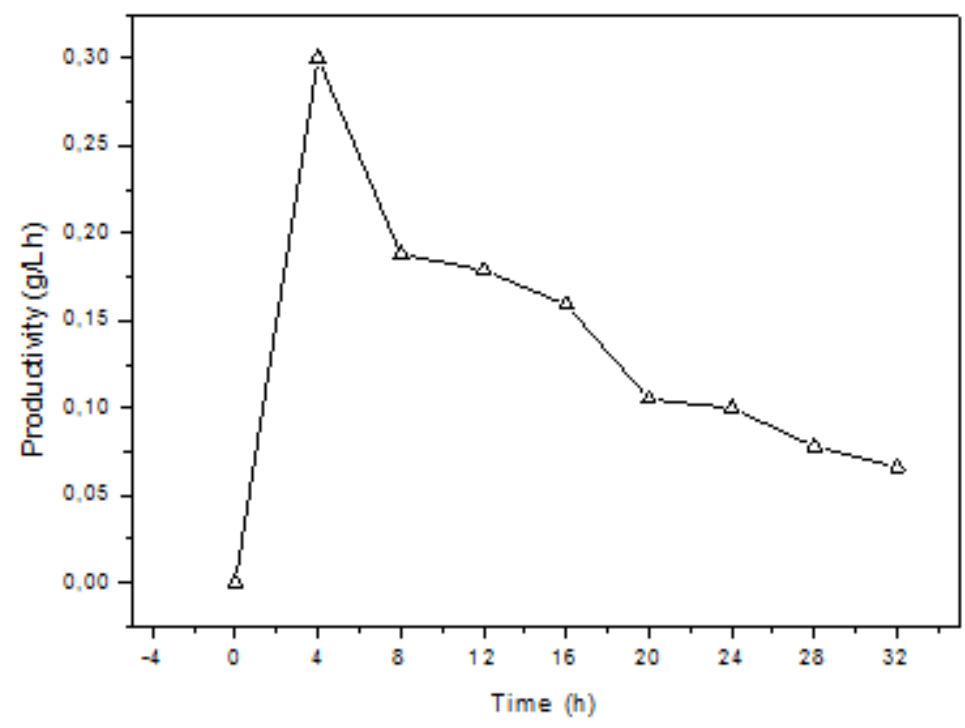

Figure 3. Productivity $\left(P_{x}\right)$ of the consortium

\subsection{The generation time}

The generation time, which corresponds to the time required for the microorganism concentration to double in exponential phase, was calculated according to Equation (5) provided by Ahmad and Holland (1995). In this equation $t g$ is the generation time (h) and $\mu_{\max }$ is the maximum specific growth rate of the microorganism $\left(\mathrm{h}^{-1}\right)$.

$\operatorname{tg}=\frac{\ln 2}{\mu_{\max }}$

\section{RESULTS AND DISCUSSION}

In the present study, thirteen bacterial strains were isolated using the technique of enrichment cultures. However, the bacterial consortium enriched from Potengi mangrove sediments was formed by just ten strains that were the best petroleum degraders.

Figure 2 shows the evolution of cell concentration of the bacterial consortium during the cultivation period of $32 \mathrm{~h}$. It was observed an 


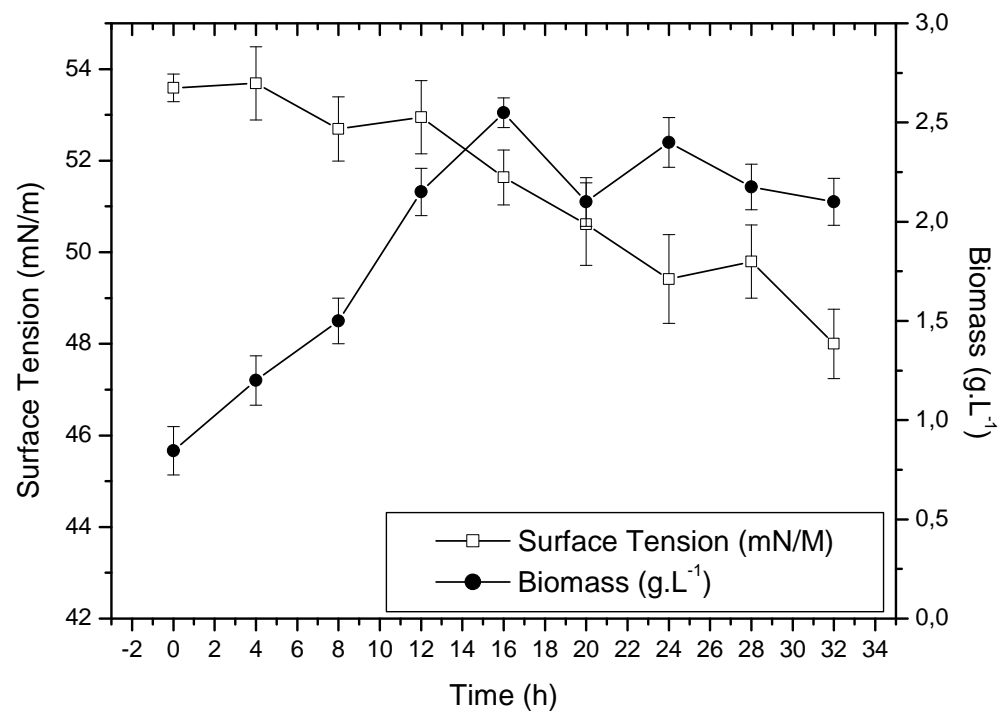

Figure 4. Curves of Biomass (•) production and variation of Surface Tension ( $\square$ ).

absence of lag phase, suggesting a good acclimation of the consortium in culture medium.

As can be seen in Figure 2 the bacterial consortium showed a final cellular concentration of approximately $2.55 \mathrm{~g} / \mathrm{L}$ for $16 \mathrm{~h}$ of cultivation. It was also observed a productivity of $0.3 \mathrm{~g} / \mathrm{L}$.h in $4 \mathrm{~h}$ as shown Figure 3.

Figure 4 shows the evolution of the surface tension and the cell concentration of the bacterial consortium during the $32 \mathrm{~h}$ of cultivation. It can be seen that the surface tension, an indirect measure of biosurfactant production, decreased as the cell concentration increased. This reduction of approximately $12 \%$ occurred in both the exponential and the stationary phase.

In light of the considerations above, there is evidence that the bacterial consortium isolated from Potengi River has the potential to produce biosurfactants. This is a finding of great importance, since the consortium could be used as inoculums in biodegradation tests to optimize the efficiency of oil degradation. The maximum growth rate was of $0,075 \mathrm{~h}^{-1}$, calculated based on the duration of the log phase and the initial and final cell concentrations. In this case, the generation time (tg) was of $9.24 \mathrm{~h}$.

\section{CONCLUSIONS}

In the process of selection and isolation of microorganisms capable of degrading oil that were present in the estuary Potengi, Rio Grande do Norte, Brazil, were obtained 13 strains of bacteria which were able to use oil as a sole source of carbon and energy. The consortium obtained showed a cellular concentration of approximately $2.55 \mathrm{~g} / \mathrm{L}$ at $16 \mathrm{~h}$ of cultivation. The maximum productivity obtained in cells was of $0.3 \mathrm{~g} / \mathrm{L} . \mathrm{h}$ in $4 \mathrm{~h}$ of cultivation. The specific speed of growth of the bacterial consortium was of $0.075 \mathrm{~h}^{-1}$, giving a generation time of $9.24 \mathrm{~h}$. The consortium was able to produce a biosurfactant that can be used in biodegradation tests to optimize the degradation process and in bioremediation strategies in the event of an oil spill or in treatment of waste oil. Future studies will be carried out in order to quantify oil degradation.

\section{ACKNOWLEDGEMENTS}

The authors would like to thank CNPq (Conselho Nacional de Pesquisa e Desenvolvimento Tecnológico) for the financial support. 


\section{REFERENCES}

Ahmad, M. N.; Holland, C. R. Growth kinetics of single-cell protein in batch fermenters. Journal of Food Engineering, v. 26 (4), p. 443-452, 1995. http://dx.doi.org/10.1016/0260-8774(94)00066-I

Alexander, M. Biodegradation and Biorremediation. San Diego: Academic Press, 2 ed., 1999. 453p.

Antonio, F. J.; Mendes, R. S.; Thomaz, S. M. Identifying and modeling patterns of tetrapod vertebrate mortality rates in the Gulf of Mexico oil spill. Aquatic Toxicology, v. 105, p. 177- 179, 2011. http://dx.doi.org/10.1016/i.aquatox.2011.05.022

APHA - American Public Health Association. Standard methods for the examination of water and wastewater. Washington: APHA; AWWA; WPCF, 20 ed. 1999. $1569 p$.

Atlas, R. M. Microbial hydrocarbon of petroleum hydrocarbon: an environmental perspective. Microbiological Reviews, v. 45, p. 180-209, 1981.

Baily, J. E.; Ollis, P.F. Biochemical engineering fundamentals. New York: McGraw-Hill, 2 ed., 1986. 984p.

Buck, J. D. Nonstaining $(\mathrm{KOH})$ Method for determination of gram reactions of marine bacteria. Applied and Environmental Microbiology, v. 44 (4), p. 992-993, 1982.

Burns, K.A. Analytical methods used in oil spill studies. Marine Pollution Bulletin, v. 26, p. 68-72, 1993. http://dx.doi.org/10.1016/0025-326X(93)90093-Y

Bouchez, M.; Blanchet, D.; Vandecasteele, J. P. Degradation of polycyclic aromatic hydrocarbons by pure strains and by defined strain associations e inhibition phenomena and cometabolism. Appl. Microbiol. Biotechnol, v. 43, p. 156-164, 1995. http://dx.doi.org/10.1007/BF00170638

Chaerun, S. K.; Tazaki, K.; Asada, R. Kogure, K. Bioremediation of coastal areas 5 years after the Nakhodka oil spill in the Sea of Japan: isolation and characterization of hydrocarbon-degrading bacteria. Environment International, v. 30, p. 911922, 2004.

http://dx.doi.org/10.1016/i.envint.2004.02.007
Costa, J. G.; Andrade, N. M; Gurgel, Y. K. P; Pinheiro, F. S. H. T; Oliveira, M. T. B.; Fernandes, M. J. B. C; Araújo, M. F. F. A novel solid medium to cultivate petroleum degraders. In: First Brazilian Symposium on Petroleum Biotechnology, 2005, Natal. Anais. Natal: Universidade Federal do Rio Grande do Norte, 2005. CD.

Costa, C. C. Avaliação da biodegradabilidade de petróleo utilizando microrganismos isolados do estuário do rio Potengi (RN). 101f. Dissertação de mestrado. Programa de Pós-Graduação em Ciência e Engenharia do Petróleo, Universidade Federal do Rio grande do Norte, 2010. (in Portuguese)

Duke, N. C.; Pinzón, Z. N.; Prada, M. C. Large scale damage to mangrove forests following two large oil spills in Panama. Biotropica, v. 29, p.2-14, 1997.

http://dx.doi.org/10.1111/j.1744-7429.1997.tb00001.x

Duke, N. C.; Burns, K. A.; Swanneel, R. P. J.; Dalhaus, O.; Rupp, R. J. Dispersant use and a bioremediation strategy as alternate means of reducing impacts of large oil spills on mangroves: The Gladstone field trials. Marine Pollution Bulletin. v. 41, n. 7-12, p. 403-412, 2000.

Fingas, M. F.; Brown, C. E. Review of oil spill remote sensing. Spill Science \& Technology Bulletin. v. 4 (4), p. 199-208, 1997. http://dx.doi.org/10.1016/S1353-2561(98)00023-1

Frazão, E. P. Caracterização hidrodinâmica e morfo-sedimentar do estuário Potengi e áreas adjacentes: subsídios para controle e recuperação ambiental no caso de derrame de hidrocarboneto. 145f. Dissertação de Mestrado. Programa de PósGraduação em Geodinâmica e Geofísica, Universidade Federal do Rio Grande do Norte, 2003. (in Portuguese)

Furukawa, K.; Tonomura, K.; Kamibayashi, A. Effect of Chlorine Substitution on the Biodegradability of Polychlorinated Biphenyls. Applied and Environmental Microbiology. v. 35 (2), p. 223-227, 1978.

Guo, C.; Dang, Z.; Wong, Y.; Tam, N. F. Biodegradation ability and dioxgenase genes of $\mathrm{PAH}$-degrading Sphingomonas and Mycobacterium strains isolated from mangrove sediments. International Biodeterioration \& Biodegradation. v. 64, p. 419-426, 2010.

http://dx.doi.org/10.1016/i.ibiod.2010.04.008 
Harayama, S.; Kasai, Y.; Hara, A. Microbial communities in oil-contaminated seawater. Environmental biotechnology. v.15, p.205-214, 2004.

Jacques, R. J. S.; Okeke, B. C.; Bento, F. M. F.; Teixeira, A.; Peralba, M. R.; Camargo, F. O. Microbial consortium bioaugmentation of a polycyclicaromatic hydrocarbons contaminated soil. Bioresource Technology, v. 99, 2637-2643, 2008. http://dx.doi.org/10.1016/i.biortech.2007.04.047

Kästner, M.; Breuer-Jammali, M.; Mahro, B. Impact of inoculation protocols, salinity, and ph on the degradation of polycyclic aromatic hydrocarbons (PAHs) and survival of $\mathrm{PAH}-$ degrading bacteria introduced into soil. Applied and Environmental Microbiology, v. 64 (1), p. 359362, 1998.

Koizumi, Y.; Kelly, J. J.; Nakagawa, T.; Urakawa, H.; El-Fantroussi, S.; Al-Muzaini, S.; Fukui, M.; Urushigawa, Y.; Stahl, D. A. Parallel characterization of anaerobic toluene- and ethylbenzene-degrading microbial consortia by PCR-denaturing gradient gel electrophoresis, RNA-DNA membrane hybridization, and DNA microarray technology. Applied and Environmental Microbiology. v. 68 (7), p. 3215-3225, 2002. http://dx.doi.org/10.1128/AEM.68.7.3215-3225.2002

Klomfar, J.; Součková, M.; Pátek, J. Surface tension measurements with validated accuracy for four 1-alkyl-3-methylimidazolium based ionic liquids. J. Chem. Thermodynamics, v. 42, p. 323329, 2010. http://dx.doi.org/10.1016/i.jct.2009.09.007

Leahy, J. G.; Colwell, R. R. Microbial degradation of hydrocarbons in the environment. Microbiological Reviews, v. 54 (3), p. 305-315, 1990.

Liria, C. W. Processo descontínuo alimentado no cultivo de Escherichia coli BL21(DE3) pLysS para produção de proteína recombinante troponina C. 128 f. Tese de Doutorado. Programa de Pós-Graduação em Engenharia Química, Universidade de São Paulo (USP), 1995. (in Portuguese)

Liu, H. J.; Yang, C. Y.; Tian, Y.; Lin, G. H.; Zheng, T. L. Screening of PAH-degrading bacteria in a mangrove swamp using PCR-RFLP. Marine Pollution Bulletin, v. 60, p. 2056-2061, 2010. http://dx.doi.org/10.1016/j.marpolbul.2010.07.013
Nakagawa, T.; Sato, S.; Yamamoto, Y.; Fukui, M. Successive changes in community structure of an ethylbenzene- degrading sulfate-reducing consortium. Water Research, v. 36, p. 2813-2823, 2002. http://dx.doi.org/10.1016/S0043-1354(01)00502$\underline{4}$

Nakagawa, T.; Sato, S.; Fukui, M. Anaerobic degradation of $p$-xylene in sediment-free sulfatereducing enrichment culture. Biodegradation, v.19, 909-913, 2008. http://dx.doi.org/10.1007/s10532$\underline{008-9192-4}$

Ramos e Silva, C. A.; da Silva, A. P.; de Oliveira, S.R. Concentration, stock and transport rate of heavy metals in a tropical red mangrove, Natal, Brazil. Marine Chemistry, v.99, p. $2-11,2006$. http://dx.doi.org/10.1016/i.marchem.2005.09.010

Sakata, S. K.; Taniguchi, S.; Rodrigues, D. F.; Urano, M. E.; Wandermüren, M. N.; Pellizari, V. H.; Comasseto, J. V. Development of a static headspace gas chromatographic/mass spectrometric method to analyze the level of volatile contaminants biodegradation. Journal of Chromatography A, v. 1048, p. 67-71, 2004.

Shim, H.; Hwang, B.; Lee, S.; Kong, S. Kinetics of BTEX biodegradation by a coculture of Pseudomonas putida and Pseudomonas fluorescens under hypoxic conditions. Biodegradation, v.16 (4), p. 319-327, 2005. http://dx.doi.org/10.1007/s10532-004-1842-6

Sindern, S.; Lima, R. F. S.; Schwarzbauer, J.; Petta, R. A. Anthropogenic heavy metal signatures for the fast growing urban area of Natal (NE Brazil). Environmental Geology, v.52, p. 731-737, 2007. http://dx.doi.org/10.1007/s00254-006-0510-z

Vasconcellos, S. P.; Crespim, E.; Cruz, G. F.; Senatore, D. B.; Simioni, K. C. M.; Santos Neto, E. V.; Marsaioli, A. J.; Oliveira, V. M. Isolation, biodegradation ability and molecular detection of hydrocarbon degrading bacteria in petroleum samples from a Brazilian offshore basin. Organic Geochemistry, v. 40, p. 574-588, 2009. http://dx.doi.org/10.1016/i.orggeochem.2009.02.006

Wardrop, J. A. The Effects of Oils and Dispersants on Mangroves: A Review and Bibliography. Centre for Environmental Studies, University of Adelaide, Adelaide, 1987. 70p. 
Zhang, Z.; Gai, L.; Hou, Z.; Yang, C.; Mab, C.; Wang, Z.; Sun, B.; He, X.; Tang, H.; Xu, P. Characterization and biotechnological potential of petroleum-degrading bacteria isolated from oilcontaminated soils. Bioresource Technology, v. 101, p. 8452-8456, 2010.

http://dx.doi.org/10.1016/i.biortech.2010.05.060
ZoBell, C. E. Marine microbiology, a monograph on hydrobacteriology. Waltham, Mass: Chronica Botanica Company, 1946. 240p. 